\title{
The Stability Imperative
}

\section{Human Rights and Law in China}

(final manuscript submitted to publisher with the title Approaching Human Rights in China: Rights and Stability) 
List of Abbreviations

ACFTU (All-China Federation of Trade Unions)

ACLA (All-China Lawyers Association)

ALL (Administration Litigation Law)

ARL (Administrative Review Law)

CCP (Chinese Communist Party)

ICCPR (International Covenant on Civil and Political Rights)

ICESCR (International Covenant on Economic, Social and Cultural Rights)

ILO (International Labour Organisation)

LDMA (Labour Disputes Medication and Arbitration Law)

$\mathrm{MOH}$ (Ministry of Health)

MOHRSS (Ministry of Human Resources and Social Security)

MOJ (Ministry of Justice)

MOLSS (Ministry of Labour and Social Security)

MPS (Ministry of Public Security)

NHFPC (National Health and Family Planning Commission)

NPC (National People's Congress)

NPCSC (Standing Committee of the National People's Congress)

PAP (People's Armed Police)

PLA (People's Liberation Army)

PRC (People's Republic of China)

RETL (Re-Education Through Labour)

SAPL (Security Administrative Punishments Law)

SPC (Supreme People's Court)

SPP (Supreme People's Procuratorate)

UN (United Nations) 
Table of Contents

Chapter 1 Rights in a Time of Anxiety about Stability

Chapter 2 Labour Rights and Stability

Chapter 3 Housing Expropriation, Demolition and Relocation

Chapter 4 The Right to Medical Care and Causing Havoc in Hospitals (Yinao)

Chapter 5 Punishing Protest

Chapter 6 Abolishing Re-education Through Labour

Chapter 7 Governance for Rights and Stability?

Appendix: Legislation

Notes

Bibliography 


\section{Acknowledgements}

Research for this book was supported by a grants from the Australian Research Council [DP0988179] and [FT130100412] and an international research collaboration, The Asia Pacific Program on Comparative and Cross-cultural Disputes Resolution Research, based at the Institute of Asian Research, The University of British Columbia. The APDR program is funded through an award from the Major Collaborative Research Initiative (Social Sciences and Humanities Research Council of Canada).

Randy Schmidt from UBC Press has shown great compassion as well as professionalism during the preparation of this manuscript for which I am most appreciative.

Even in the most difficult times I have been fortunate to have the unswerving love and support of David and my parents, Richard and Alison.

I am grateful to the wonderful research assistants who helped with this project; Ren Shuang, Zhang Xinyu, Ma Chenjie and Alistair Robertson.

References to legislation are current as at 1 June 2014. 
Chapter 1 Rights in a Time of Anxiety about Stability

In his 1980 speech, The Present Situation and the Task before Us, Deng Xiaoping acknowledged the years of suffering of the Chinese people as a result of political campaigns and political instability. He determined that policies would be implemented to make the country rich and strong, to 'develop the productive forces and gradually improve the people's material and cultural life' (Deng 1980, 2367). The precondition for achieving this objective was political stability and unity. From the outset of the program of economic reform and opening up, the China's one-party state (the Party-state) ${ }^{i}$. has promised to improve people's material and cultural life as part of national development. It has always been preconditioned on stability.

Since then the Party-state has moved away from its Marxist rejection of human rights and embraced the rhetoric of protection of individual human rights. China has signed and ratified many of the major international human rights instruments and embedded a commitment to the protection of human rights in the Constitution (article 33). Arguably, together with rule of law, the protection of human rights has become an important basis for governance. In June 2012, the Chinese government released its most recent human rights policy document, the second National Human Rights Action Plan (the 'Human Rights Action Plan') for the period 2012-2015. It contains a clear affirmation of the Chinese government's obligation to respect and safeguard human rights and sets out a wide-ranging plan gradually to improve both social and economic, and civil and political rights. As a document, it addresses a number of audiences: it is outwardly directed to the international community, which is increasingly engaging with China on human rights issues, and inwardly directed to China's citizens, who are increasingly demanding that their rights be respected. It is as much hortative and symbolic as it is an official statement of achievements and plans for giving effect to human rights in China. And, it is an attempt by the Party-state to define and control the scope and meaning of human rights in China.

As the 2012-2015 Human Rights Action Plan makes clear, the Party-state's primary human rights focus remains national development and as part of that the right to subsistence, to material assistance when in need and to improving people's livelihoods. The Human Rights Action Plan goes on to articulate a desire to safeguard citizens' economic, political, social and cultural rights and promote social equity and harmony, so as to ensure that every member of society lives a happier and more dignified life' (State Council Information Office 2012, Introduction). Such a focus is not new. Elizabeth J. Perry points out that there has been a very long history of the Chinese state giving priority to protection of the people's livelihood and to perceptions that failure to do so brings the threat of social instability $(2008,39-40)$. As a policy and governance objective, giving effect to fundamental rights becomes inextricably linked to social and political stability.

By 2014 China has become both rich and strong. But the promise to improve people's livelihoods and the aspiration to enable every member of society to lead a happier and more dignified life has been imperfectly realised. In fact growing inequality between different groups in society has led to growing social instability. One commentator, Zhou Ruijin, identified the following main issues as contributing to what he calls 'public indignation':

'The gap between the rich and the poor has widened in the absence of a fair and rational system to distribute China's economic prosperity; 
Social welfare lags behind economic development, failing to establish a social security system capable of benefiting all in society;

The public's sense of happiness is decreasing as a result of failures in tackling problems of basic livelihood, like education, healthcare, housing, employment, etc;

Environmental pollution is worsening as high investment and high-pollution industries continue to emerge. Food, water, and air are polluted. The sharp conflict between economic development and environmental protection is on the verge of explosion and has triggered many mass protests; and

Corruption takes root not just in economic activities, but also in officialdom, the administration of justice, the media, and education. Corruption is directly correlated with institutional defects. (Zhou 25 February 2013)

The increasing levels of public anger over failures to address basic concerns about livelihood are increasingly being aired in public through complaints, protests, strikes, appeals and petitions to Party and state agencies, and in extreme cases, through large scale or violent protests suicide and murder. Of concern is that whilst a large number of grievances are being addressed through formal dispute resolution channels an increasing number are being pursued outside these channels. Not all forms of public protest and disruptive conduct are rights related, but the vast majority are. A 2012 report on mass incidents (quntixing shijian 群体性事件) published by the Legal Daily, suggests that mass incidents fall into three broad categories: rights protection, which are primarily in response to harms to people's livelihood (weiquan 维权), anger venting (xiefen 泄愤) and disturbances (saoluan 骚乱). Professor $\mathrm{Yu}$ Jianrong concludes that over $80 \%$ of mass incidents are related to rights protection ( $\mathrm{Yu}$ 9 April 2009b). Handled badly, they have the potential to transform into serious public order incidents.

Clearly, the disjunction between the rhetoric of human rights and the reality of day to day administration and people's lived experience raise questions not just of evaluation but of explanation. What are the ideological and institutional filters through which these human rights promises are shaped and given effect? How do other policy priorities, such as preservation of social order, impact on the interpretation and implementation of these rights promises? How are human rights promises to be reconciled with the realities and priorities of governance in China's Partystate? The growing number of mass protests and the state's response to them highlights a tension that plays an important role in shaping and limiting the scope of human rights. That is, the state's obsession with social order and stability, and by extension, political stability. The particular ways in which the Party-state pursues its objective of social stability are a core concern in any examination of legal and institutional engagement with rights.

The legal system is a core institutional determinant of rights. At the official level, establishment of China's version of rule of law is seen as key to articulating and giving effect to human rights. This linkage was reiterated in the Human Rights Action Plan with the statement that the "socialist legal system with Chinese characteristics has been established to provide legal support for all fields of social life and all aspects of human rights protection" (Human Rights Action Plan section 1). As the legal system is so closely associated with the realisation of human rights promises, it is appropriate for us to look carefully and critically at the ways in which the legal system embodies or defines 
human rights and to evaluate the mechanisms the law makes available to give practical effect to those rights, or to pursue human rights based claims. Despite the clear link between law and human rights in the Human Rights Action Plan, it is not apparent that the Chinese legal system provides effective mechanisms to protect them. In fact, as is the case with legal systems everywhere, the legal system has many functions and reflects a range of priorities; economic growth and increasing state power being amongst their core. Two others are the protection of human rights and the maintenance of social stability. Ultimately they all focus on the primary objective which is preservation of the political power of the CCP. So how does this obsession with 'stability above all else' impact upon rights protection? This is the central question explored in this book.

This book examines the ways in which rights are given effect and implemented in China's domestic environment. It explores the multifaceted relationship between these rights and social stability. Its focus is thus primarily on domestic law, policy and practice, rather than on an examination of the meaning of human rights in international law, or China's institutional engagement with international human rights organisations. This book looks in particular at three specific examples of the relationship between rights and stability in areas that impact directly on peoples' basic livelihood; labour (chapter 2), forced housing eviction and relocation (chapter 3 ) and medical care (chapter 4). It examines the ways in which disruptive behaviour and individuals considered to pose a risk to social order are managed, controlled and punished (chapter 5). Finally it examines the relationship between rights and stability in the context of the protection of personal liberty, which is a fundamental component of personal dignity. It does so through a discussion of the abolition of reeducation through labour (chapter 6).

Scholarly examinations of different aspects of China's legal system have considered a number of ways in which stability preservation impacts on legal protections of rights. Randall Peerenboom argues that enjoyment of rights is properly subordinated to the need to preserve stability. He says 'stability is a pre-requisite for the enjoyment of all rights. The need to ensure economic development and stability justifies limitations on the exercise of civil and political rights' (Peerenboom 2005a, 80). Another approach is that social and political stability are the basis upon which human rights may be enjoyed. Social stability on this view is the greatest guarantee of human rights (Ren 2005, 27, 30). Extensive empirical studies on the role of courts in adjudication by He Xin Benjamin Liebman, Carl Minzner, amongst others point to the ways stability goals and the fear of protest overshadow administration of justice according to law (Liebman 2011); (Liebman 2013); (He 2007); (Su and He 2010); (Minzner 2011). The case studies in this book reveal a range of formulations; rights protection used rhetorically and in practice as a means of promoting stability, a view of rights protection as existing in conflict with stability protection, and the imperatives of stability protection acting as an incentive to abrogate rights and to use repressive force. A detailed examination of the ways in which stability imperatives impact on the definition and realisation of rights in the case studies helps to unpick how these tensions underpin the evolving legal structures and priorities of governance. It provides a perspective on the policies and imperatives instrumental in shaping China's particular version of the rule of law. The core issues explored in this book focus on the ways in which rights are defined and given effect by law, their interaction with the Party-state's understandings of the causes of social instability and institutional structures for stability preservation. Some further explanation of these core concepts provides some background to the detailed discussions that follow. 
$<2>$ Stability

As Deng Xiaoping famously proclaimed on 26 February 1989: '[o]f China's problems, the need for stability overrides all else. Without a stable environment, nothing can be achieved, and all that has been achieved will be lost (People's Daily Online 26 June 2001). According to this prescription, not only the successes of economic reform are imperilled, but so is political stability and continuation of CCP rule as they are closely linked to social instability. Since 1989, the maintenance of social stability has been a core priority of the CCP. After installation of the new generations of leaders under Xi Jinping, there has been no lessening of the focus by senior leadership on stability preservation. $\mathrm{Xi}$ affirmed that not only the Party but also all Chinese people want stability and fear chaos (Yuen 2014a), 2. (Yuen 2014a) argues that the legitimacy of the state is staked on its capacity to maintain social order. On this view, maintenance of stability is not merely a basis for economic growth and a marker of legitimacy, but the Party-state's capacity to maintain social order is the basis of its legitimacy. 'It is a mark of popular consent to the Party-state' (Yuen 2014a, 2, 5-6).

The question of what social condition is seen as being stable is fundamental both to interpretations of the nature of the threat posed by socially disruptive conduct including mass incidents and to the nature of the Party-state's response to these threats. Professor Yu Jianrong, one of China's best known scholars of petitioning and mass incidents in China, sets out two ideal types; rigid stability and resilient stability. Rigid stability tends to view society as inherently unstable and so needing active state intervention to maintain order. It is centred on the CCP maintaining its monopoly of political power and requires absolute social order. It tends to construe any disruption of social order as undermining political stability and requiring intervention. The stability preservation offices set up at all administrative levels of the Party-state are responsible for maintaining order and social harmony. At the local level, protests can readily be interpreted as an assault on local power and so a form of instability. Through this lens, conduct such as petitioning or other mass incidents readily become seen as destabilising, rather than as a vehicle for making legitimate claims (Yu 26 May 2009).

Resilient stability on the other hand, requires that more sustainable long term stability be based on observance of the law and the Constitution. Stability is constituted through stability of the political system and institutions of state based on the rule of law. This model sees stability as being based on norms of justice and equity, or at least mitigating injustices such as; an insecure and unfair employment market, unequal opportunities and access to education and health care and expropriation of land especially rural land without proper procedures and compensation. The 2005 UNDP Human Development Report defines justice as follows:

Justice is a value and a norm for making judgment calls on social practices and human relations. As a concept, it involves "fairness" and "goodness" and is highly normative. Social justice is a moral pillar indispensable for any society, a basis for members of a society to reach consensus and cooperate, and a basis for resolving conflicts (UNDP 2005, 5).

Such a model of stability would not be so quick to construe all socially disruptive conduct as constituting a fundamental threat to stability. The problem, according to Professor Yu, is how to move from a model of rigid stability to one of resilient stability. Initial hopes in early 2013 that the new CCP leadership under Xi Jinping would move toward greater respect for the rule of law and constitutional governance appear to have been misplaced. Leaking of Document \#9 issued by the 
General Office of the CCP Central Committee in April 2013 indicates Party resistance to further strengthening principles of the rule of law and constitutional governance. Document \#9 attacks inter alia western constitutional democracy and those who attack Party leadership by asserting that the CCP be subject to the Constitution and governance according to law (Lubman 27 August 2013).

It is also significant that the conceptual framework provided by Mao Zedong's theory of contradictions is still commonly used in the discussion of stability and to analyse conflicts and disruptive conduct. Mao divided contradictions into antagonistic contradictions, those between enemies and the people and non-antagonistic contradictions, those amongst the people.

Antagonistic contradictions are to be resolved by coercion and repression. Non-antagonistic contradictions, on the other hand, are to be solved by 'the democratic method, the method of discussion, of criticism, of persuasion and education...' (Mao 1972). Within this repertoire, for example in the handling of labour protests, we see the use of mediation, persuasion and even ex gratia payments of unpaid back wages from special local government funds to persuade protesters to disperse. On the other hand, where protests that might have been sparked by accumulated grievances escalate into violence, such as the riot in Zengcheng, Guangdong in 2011, they are dealt with as antagonistic contradictions, and suppressed with great force.

The emphasis on stability preservation, coupled with institutional pressures on local agencies to ensure social stability has, perversely, led to increasing abuse of punitive powers such by local governments and officials (Ren, Wang, and Jia 9 January 2013). As discussed further in chapter 5 , the Party-state has constructed an extensive and pervasive institutional structure to implement stability preservation (weiwen) policies. Stability preservation has the capacity to be both intrusive and abusive and implemented at the expense of rights protection. The question Yuen (2014a) raises is whether the Party-state's efforts to re-legitimate itself through the policies and institutional mechanisms it has adopted to preserve stability have, perversely, undermined its legitimacy. He would conclude in the affirmative.

$<2>$ Mass incidents

At a time of social dislocation and growing inequality as a result of economic transformation it is not surprising that there has been an upsurge in mass incidents. These take the form of small group petitions, sit-ins, strikes, rallies, street processions, to fighting and riots (Tanner 2004, 138).

Professor Yu Jianrong defines a mass incident as having four characteristics. First there must be more than five people participating. The Letters and Visits Regulations, for example define group petitions comprising over 5 people as an 'incident'. The second characteristic is that the group must carry out conduct together. Third, that procedurally they lack legal authorisation. And fourth, they affect order, especially financial or social order. Mass incidents take many forms including rallies, marches assemblies, demonstrations, strikes, group petitioning, skip a level petitioning, occupying roads, railways other public places (Legal Daily 2012). Based on this definition there were 8,709 mass incidents in 1993 and 90,000 in 2006 (Yu 9 April 2009b). The Ministry of Public Security stopped releasing statistics after 2006 . One scholar is quoted as asserting that in 2010 , the number of mass incidents had risen to 180,000 (Forsythe 13 June 2011, Fewsmith 6 January 2012).

Of the $80 \%$ of mass incidents that related to assertions of rights, Professor Yu argues that the vast bulk relate to economic problems and can be resolved through the payment of a monetary amount. Official interpretations of mass incidents concur, characterising the bulk as reflecting 'contradictions 
amongst the people' that is, conflicts over material interests. That is the main causes of mass incidents are issues such as delayed payment of wages, compensation for land expropriation or compulsory housing eviction and demolition, excessive tax burdens or illegal financial exactions, conduct having a direct impact on their personal livelihoods (Ren 2005, 49, 259). A study of large scale (involving over 500 people) mass incidents between 2003 and 2009 found that the bulk, 45\%, were labour disputes relating to re-structuring of state-owned enterprises and disputes over wages and working conditions in private enterprises. The second most common category was disputes over land expropriation and forced housing relocation (Tong and Lei 2010, 491-3). Middle class protests seeking to prevent construction of environmentally damaging industries in the proximity of urban areas or developments that might affect the value of properties have also become prevalent. The significance of characterising the bulk of mass incidents as non-antagonistic contradictions is that in theory they should be dispersed without resort to violent suppression.

The overwhelming bulk of 'rights asserting' mass protests are framed in terms of rules rather than rights. They are mostly reactive (responding to specific incidents and aggravations) rather than proactive and involve both lawful and unlawful conduct (Yu 9 April 2009b). Whilst most are fragmented, there is evidence that some protesting groups are linking up (Tanner 2004, 142). As the analysis in chapter two suggests, the reactive and fragmented nature of protests at least in relation to labour disputes, may be changing. Extensive social research conducted by Martin Whyte support the view that increase in the number of mass incidents should not necessarily be interpreted as opposing the Party-state or the existing political regime. Whyte's research suggests that income inequality per se may not be enough to lead to popular resentment and social instability. His research points to acceptance of unequal distribution if it is based on individual hard work, education or talent, but less willingness to accept income disparities based on factors such as personal connections and unequal access to opportunities (Whyte 2010, 47). Since the mid-1980s the Party-state has engaged in wave after wave of legal education campaigns which have resulted in growing rights consciousness. But still many claims by citizens and groups are framed in terms of moral claims to subsistence, rather than as an assertion of a new form of political citizenship and so it is important to not over-interpret the significance of either mass incidents or rights discourse in these areas. Perry rightly points out that protests may be framed as demands to protect subsistence rights, or to follow the rules and not framed as a challenge to the political order $(2008,44,46-47)$. Protests may be one of the mechanisms by which higher levels of government obtain information and deal with local abuses, and so contribute to stability.

Mass incidents characterised as 'anger venting' or 'riots', such as the Weng'an incident on 30 October 2007 or riots arising out of ethnic tensions, are dealt with using force. The Weng'an incident began with the death by drowning of a young woman, Li Shufen. Her death was found to be by suicide, but many suspected she had been murdered by her boyfriend who was the son of a senior local official. On the way to the police station to make a complaint her uncle was set upon by unknown thugs and seriously injured. When news of this spread many came onto the street to protest and a riot ensued. It was only controlled after 7 hours with many buildings and cars burned and around 150 people injured. Of note was that many people joined the protest despite not being directly affected by the original cause of the protest. There was evidence of wide-ranging accumulated grievances about injustice and bad treatment at the hands of local officials, particularly in forced relocation of many residents and migrant workers to make way for the development of mines (Yu 9 April 2009b), (Tong and Lei 2010, 498). This riot attracted the attention of central 
authorities, with the then Minister of Public Security, Meng Jianzhu, leading the riot response by telephone (Tong and Lei 2010, 494). This incident shows how small triggers can transform into anger venting mass incidents and, if handled badly, into riots (Yu 9 April 2009b), (Ren 2005, 31). Studies of mass incidents that have escalated into violence indicate that poor handling or failure to address grievances at the outset by local officials or police play a significant role in their escalation (Mo 2011); (Tanner 2004, 148). That one incident could trigger a riot indicates the depth of accumulated grievance against local authorities, which is harder to address than protests that can be dealt with by the payment of money. It is thus indicative of broader legal and institutional failures. This type of disturbance has increased in comparison with economically motivated mass incidents (Tong and Lei 2010, 494).

The police who are often called upon to deal with protests are not without sympathy for protests they see as based on a legitimate grievance. (Chung, Lai, and Xia 2006), (Li 1999b), (Tanner 2004, 144-5). In many circumstances demands of the protesters are accommodated as a way of dissipating the protest, or no action was taken (Su and He 2010), (Tong and Lei 2010, 501). However, when these conflicts become 'confrontational' in form, policing responses are affected (Ren 2005, 259-63). Many protests are becoming larger, better organised and more violent as the underlying grievances are not satisfactorily resolved (Wang 9 October 2001), (Tanner 2004, 140-1). If they are handled appropriately social stability may be enhanced. If, however, they are handled inappropriately, what might have started as a conflict over material interests has the potential to intensify, to become increasingly confrontational and to seriously undermine social stability (Ren 2005, 49).

$<2>$ Petitioning (letters and visits)

Mechanisms for receiving and dealing with citizen complaints preceded establishment of the PRC. From 1951 special offices were established to receive citizens' complaints and criticisms. These were re-established soon after adoption of the economic reform and Open Door Policy. Article 41 of the Constitution authorises citizens to criticise and make suggestions regarding any state organ or functionary and to bring complaints against state organs and functionaries for violation of the law or dereliction of duty. It requires state organs to deal with these complaints. One way this constitutional protection has been given institutional form is by establishment of letters and visits offices in Party, government and judicial organs from 1982 following adoption of the Temporary Regulations on the Letters and Visits Work of Party and Government Organs (Zhang 2012a, 31). Complaint making through letters and visits was further institutionalised by the State Council Letters and Visits Regulations passed first in 1995 and then in 2005.

Between 1979 and 1982 letters and visits primarily dealt with historical problems where people sought to have adverse judgments imposed in the Cultural Revolution set aside (Luehrmann 2003, 855). From 1982 letters and visits transformed into a venue for resolving individual and collective grievances (Zhao 5 November 2004). Complaints may be brought to letters and visits offices established in all state and Party organs including courts at all levels. Complaints need not be framed in terms of lawfulness of conduct. This is one strength of the system, in that a grievance can be raised without having to conform to legally framed causes of action. At the same time it is a weakness as the process for resolving the dispute is less formalised and runs the risk that the problem will not be resolved at all. Officials are tasked with dealing with these complaints, sometimes by investigating themselves, but more frequently by referring the complaint back to the 
local agency that is the subject of the complaint. Luehrmann (2003) reported a trend to increasing numbers of complaints starting from the mid-1990s. These numbers continued to increase into the early 2000 s.

From around 2003, the hope that the new leadership of Hu Jintao and Wen Jiabao might respond more favourably to petitions led to a massive increase in petitioners to Beijing (Li, Liu, and O'Brien 2012 , 320). Petitioning to Beijing in particular is seen by many as a way of putting pressure on local authorities to address the complaint (Yu 2 December 2004). In addition to an increase in the volume of petitioning, there has been a gradual escalation of the disruptive or confrontational tactics used by petitioners. To many petitioners, repeat petitioning, skipping a level petitioning (petitioning to government a level higher than the agency against which the complaint is made) and disruptive conduct as part of petitioning is seen as a way of making the protest more effective (Chen 2007b, 255). Many feel that only by making a big fuss will there be a big resolution to their problem, whereas creating no fuss will lead to no resolution at all (Chen 2010b, 192). A range of disruptive and troublemaking strategies employed include large scale street protests, storming public buildings and large scale sit-ins in public places (Li, Liu, and O'Brien 2012, 321-3). Those petitioners who engage in strategic troublemaking designed to put pressure on officials to address their grievance risks crossing the boundary between lawful and unlawful conduct (Chen 2007b). In extreme circumstances petitioners have taken violent measures such as blowing up buildings and committing suicide by selfimmolation.

Since 2004 the central government has applied pressure on local governments to ensure that they either deal with petitioning (or the problem that gave rise to the petitioning in the first place) locally, or prevent petitioners from reaching Beijing. The target management performance appraisal system has also been brought to bear as a way of pressuring local officials to prevent petitioners travelling to Beijing. In 2006 satisfactory performance appraisal was made conditional upon meeting petitioning targets. As a consequence, local officials may be subject to official criticism, punished, have their bonuses docked, or their chances for future promotion prejudiced if they failed to prevent petitioners from reaching Beijing, or if mass incidents arise from failure to deal with petitioning.

Local authorities have responded in a number of ways. One has been to adopt a range of punitive and repressive measures to meet those targets (Li, Liu, and O'Brien 2012, 325-6); (Human Rights Watch December 2005, 7); (Human Rights Watch 2009, 9); (Minzner 2009-2010, 57). An example discussed in chapter 3 is the escalation in petitioning against forced demolition and eviction in Shanghai in the early 2000s. On several occasions from 2003 police arrested petitioners as they departed by train for Beijing and others were detained by the Beijing Municipal Public Security Bureau after arriving in Beijing (CECC 2005); (Wilhelm 2004, 283); (Human Rights Watch March 2004); (Human Rights in China 19 July 2005).

Another is to do anything needed to solve petitioners' grievances to make the problem go away. One academic argues that the amount of publicity given by mainstream media to the willingness of governments to do anything needed to solve petitioners difficulties has fuelled a belief that petitioning is more effective than pursuing claims through judicial channels (Liu 4 September 2013). This belief, coupled with the cadre responsibility system which punishes officials based on the volume of collective and skip a level petitions from their jurisdiction has, perversely, contributed to an escalation of socially disruptive behaviour (Yu 2 December 2004); (Minzner 2006, 156-7). Despite 
regulations that severely circumscribe complaint making to higher level departments, both repeated petitioning and skip a level petitioning continue to remain high. For example in Taizhou, Zhejiang province there was a 76\% increase in the number of repeat petitions between the first half of 2006 and the first half of 2007 (Jiang 2007, 52)...

Minzner argues that the petitioning system is only marginally interested in resolving individual grievances. He argues, with some justification, that the system is a management technique. That it operates as a mass line instrument more generally interested in maintaining official connections with the masses, directing thought, monitoring the conduct of officials, maintaining social order and enabling citizen input into policy making (Minzner 2006, 120-121). A major report on petitioning lead by Professor Yu Jianrong released in 2004 supports this conclusion. This report received high level attention not least for the abysmally low rate at which petitioners' grievances were successfully resolved: two cases in 1,000 (Zhang 2012a). It also fed into a debate about how to reform the system of letters and visits. One view was that the system needed to be legalised and regularised. Yu's view was that it should be allowed to disappear as it had transformed from a system to collect and deliver information to the public into a dispute resolution mechanism of last resort that undermined the authoritativeness of judicial dispute resolution (Zhang 2012a). The then head of the Central Politicallegal committee, Zhou Yongkang, expressed the view that the letters and visits system needed to be regularised and strengthened. He emphasised a key to social stability lay in resolving issues raised through the system of letters and visits lawfully and efficiently (Feng 3 November 2011). New Letters and Visits Regulations were passed in 2005. Zhou Yongkang commented that these regulations were passed to legalise and standardise the system of letters and visits. They ensured that the system of letters and visits would not fade away and that they were expected to provide a positive intervention in promoting a harmonious society (Xinhua Net 21 February 2005). As discussed further in chapter 5 , after passage of these regulations, more restrictive conditions have been placed on petitioning conduct and punishments clarified for those who engage in 'abnormal' petitioning.

$<2>$ Stability protection and social management

Preserving social stability has long underpinned social order and policing priorities. The Party exercises organisational leadership over the civilian coercive apparatus and law enforcement policy and practice through its Political-legal Committee (zheng fa wei 政法委) which comprises representatives of the police, people's armed police, state security, People's Courts, People's Procuratorates and justice agencies at each level (Biddulph 2007, 232-4). In 1981 the policy of Comprehensive Management of Public Order (CMPO) was adopted as the umbrella for coordinated management of the Party-state's social order and crime control activities. After 1989 the centrality of stability and its positive role in economic modernisation was reasserted (Yuen 2014a, 10). In 1991 the Comprehensive Management of Public Order Committee was established to strengthen Party control over social order policy and its enforcement at the local level. The program was designed to provide a comprehensive umbrella involving Party, government and public actors in preserving stability and punishing crime (Biddulph 2007, 103-5, 107-9). Its focus was not merely on punishment of offending but also prevention through education, oversight by local resident and village committees, and the management of targeted populations and locations (Biddulph 2007, 103-9). Even in 1991 the Party-state's capacity to exercise comprehensive control over society had weakened (Dutton 1995, 314). Policing policy had become reactive rather than proactive (Wong 2002,309 ). More than twenty years later, the processes of pluralisation of individual, economic and 
state interests have effected an even more dramatic transformation on society. It is now even more difficult for policies and programs that purport to exercise comprehensive oversight and control to be implemented in the ways their design might suggest.

One report suggests that the focus on social order and crime was expanded in the mid-late 1990s by the CCP's Central Committee to encompass a broader, multi-agency stability protection mechanism to respond to the social unrest arising from restructuring and bankruptcy of state-owned enterprises (Liao 14 April 2009). Trevaskes argues that 'protection of social stability' (weihu wending 维护稳定 abbreviated to weiwen 维稳) was officially coined in 2003 as a term and designated as a new policing priority to address social order problems caused by mass incidents $(2013,61-2)$. At that time a report commissioned for the CCP's Central Committee evaluated the harm caused by social instability and mass incidents as: damaging the image of the government and Party, threatening the authority of the law, threatening political stability and community respect for order (Trevaskes 2013, 63-4). Mass incidents thus became seen as a much more of a threat to social and political stability than a nuisance and have become the focus of comprehensive social order and policing priorities under the rubric of 'stability protection' (weiwen). The main types of conflict identified as driving the increase in mass incidents was the growing conflict between: 'rich and poor, government officials and the masses, labour and capital, people from urban and from rural areas, Han and various ethnic minorities and people from different regions within China' (Trevaskes 2013). These factors map nearly exactly the main sources of social and distributive injustice identified by Zhou Ruijin above.

Whilst the case studies in this book document the Party-state's responses to ameliorate the substantive injustice underlying these social tensions, these social order contradictions have also driven development of an institutionalised social order response to the fact of social instability. These responses lie at the heart of the multiple layers of tension between protection of rights and protection of stability explored in this book. Public spending on 'stability protection' has skyrocketed. The budget for domestic stability protection in 2011 was RMB 624.4 billion (USD 95.18 billion), greater than the publicly declared military budget for 2011 (Lam 2011).

A Party-state apparatus comprising social stability committees has been established at all levels of the government and Party hierarchy under the leadership to the CCP's Comprehensive Management of Public Order Committee, Leading Group Office (the 'Stability Preservation Office'). This office plays a central role in coordinating policies on social management, early warning and management of mass incidents. Membership of Stability Preservation Offices at each level mostly comprises Party and state officials, representatives of mass organisations such as unions and the Women's Federation. It also relies on information provided by local Village Committees, Street Committees and Resident's Committees. This system is discussed in more detail in chapter 5.

From 2010 the CCP's Politburo expanded the program of stability protection into a broader approach to governance under the rubric of social management (shehui guanli 社会管理)with a view to dealing with the growing number of mass incidents and the concern of the impact they are having on the legitimacy of the Party (Fewsmith 6 January 2012). In 2011 the name of the Comprehensive Management of Public Order Committee was changed to the Committee for the Comprehensive Governance of Social Management, which reflected a merging of the social order functions of the old committee with economic objectives of reducing inequality and devolution to NGOs and community volunteers of the provision of some public welfare services (Sapio 2014, 251-2). The aims of social management are elaborated in the $12^{\text {th }}$. Five Year Program for National Economic and Social 
Development (12 ${ }^{\text {th }}$. Five-year Plan, chapter 37). Replicating the 2006 Central Committee Decision on Several Major Questions on Building a Harmonious Socialist Society, iii. it outlines a more 'peopleoriented' approach to governance. Social management includes strengthening the capabilities of the Party to lead, organise, manage and serve society, strengthening 'dynamic management' to 'resolve the masses' legitimate and rational appeals' (Fewsmith 6 January 2012). It also resolves to establish emergency management mechanisms to deal with sudden or unexpected incidents (tufa shijian 突发 事件).

Approaches to social management are illustrative of broader governance patterns and priorities. It reflects a view that society has to be managed to be stable, with law providing the 'framework and ground rules' (Pieke 2012, 155). It is in conception a state corporatist project designed to co-opt and subordinate interests of individuals, the collective and society to the Party's vision and agenda. In this respect the program of social management goes beyond the pre-existing program for the comprehensive management of public order developed from the beginning of the reform era. Social management mechanisms are conceived as follows: they are 'under the leadership of the Party, the government is responsible, society cooperates and the masses participate'.

The concept of social management extends further than a focus on crime and order through its emphasis on promoting social harmony to touch on dispute resolution, the provision of social services and recruitment of volunteers into stability management work. Justice agencies; the police, People's Procuratorates, People's Courts and Justice departments all have a role to play in implementing social management policies, to resolve disputes in order to promote harmonious social relations, to reduce social contradictions and realise fairness (Nesossi 2014 (forthcoming), 225-6). In subsequent chapters we will see these ideas reflected in the emphasis on mediation as a way of resolving disputes and promoting social harmony, by courts and other agencies.

Social management and stability protection policies provide that primary responsibility for implementation of these programs lies with local government. The cost of funding stability protection initiatives has not been fully met by the central government and so the financial impost on local governments, particularly in poor areas, is heavy (Xie 2013). Local governments shoulder the primary responsibility for resolving disputes and disruptions at the local level. Officially they are required to achieve stability through adherence to the rule of law (Hu and Yue 6 August 2013). But the interests of the local state do not always coincide with central programs or with some aspects of them. A key to understanding the incentives for local government to engage with these programs and to undertake responsibilities allocated to them lies in the target management responsibility system (mubiao guanli zerenzhi 目标管理责任制) which forms the basis for annual performance evaluation. The annual local cadre performance appraisal affects individual's prospects for promotion and the payment of performance bonuses and acts as a strong motivator in prioritising certain responsibilities over others (Whiting 2004), (Minzner 2009-2010). The maintenance of social stability has been designated one of the most important performance targets, designated as a 'onevote veto' (yi piao foujue 一票否决). As a result, a single social order incident can negate all other achievements for that year (Feng 2013).

An example of how the 'one-vote veto' works in practice comes from Qujing in Yunan. It provides that where there has been a serious social order incident in the previous year, the leaders with responsibility may receive a range of sanctions including: not being able to receive an assessment of 
'good' (youxiu 优秀); being reported and shamed to the municipal government; being required to submit a written self-criticism; or dismissal where the leader has received a grade of bad (cha 差) for two consecutive years. Responsibility for serious social order incidents is not confined to the county government leadership, with county level leadership officials attributed $70 \%$ of the blame and municipal level leadership officials allocated $80 \%$ of the blame. ${ }^{\text {iv }}$. It should not be surprising then that local officials respond to mass incidents in a range of ways; either they are particularly vulnerable to pressure and so more willing to resolve the dispute regardless of the legalities (Li 2013), or they may adopt forceful measures to suppress the protest and punish the participants (Feng 2013).

Recent policy emphases on Party and state-led mechanisms for social management, coupled with an understanding of social order in terms of rigid stability readily leads to the interpretation that socially disruptive conduct is damaging to society as a whole and to political stability. The discussion in following chapters demonstrates how this conception of social and political stability creates a tendency to construe disruptive protests as 'abnormal' and even as an emergency requiring an emergency response.

$<2>$ Rights, Justice and Law

After the Tiananmen Square massacre in 1989, the critical attention of the world focused on the protection of human rights in China (Kent 1993). In response, the Chinese government issued a White Paper in 1991 entitled Human Rights in China in which it articulated its vision of human rights. This vision of human rights claimed the right to subsistence as the 'foremost human right' of the Chinese People. It stated: '[I]t is a simple truth that, for any country or nation, the right to subsistence is the most important of all human rights, without which the other rights are out of the question.' It goes on to elaborate: '[T] he preservation of national independence and state sovereignty and the freedom from imperialist subjugation are, therefore, the very fundamental conditions for the survival and development of the Chinese people.' (State Council Information Office 1991).

This White Paper articulates a state-centred approach to human rights which is based on a view that there is an identity of interest of the nation and its citizens. It gives priority to the nation's right to development and links strengthening the nation and increasing its wealth through economic development to the enjoyment of individual social and economic rights. These rights are framed in terms of capacity to participate in and enjoy the fruits of economic development. Citizens' rights in this formulation are considered to be dependent upon and subordinated to the nation's right to development (Liu and Cooney 2010). Conceived in this way, social and economic rights are not exercised as claims against the Party-state, but are derived through and provided by it. The nation creates and gives effect to the rights enjoyed by its citizens.

In the aftermath of the social upheaval in 1989, the Party-state went on to develop human rights policies that sought to balance economic reform and social stability. These included programs for improvement of housing, provision of social insurance and reforms in the provision of health care (Kent 1993, 199-201). As we see in the case studies, rights related to health, housing and labour are framed as core elements of the basic right to subsistence promised by the Party-state and enjoyment of these rights is understood to be closely related to the preservation of social stability. But since 1991 there has been growing inequality in income and access to social goods, while urban 
development schemes have rendered both housing and land use rights insecure. So the issue of human rights and its relationship to social stability has again come into focus. The most recent Human Rights Action Plan continues to link the promotion of human rights to national development by stating that 'human rights endeavours' are 'combined' with 'economic, political, cultural, social and ecological construction' (State Council Information Office 2012).

China has not given equal weight to the protection of civil and political rights and continues to impose severe limitations on freedoms of speech, religion and association. China has also been criticised over many years for its systems of arbitrary detention under a range of administrative powers. Many now argue that a view of human rights that focuses on the rights to development and subsistence to the exclusion of civil and political rights cannot be sustained. Enjoyment of all human rights, they argue, is necessary to assure the dignity of the person (Minkler and Sweeney 2011). Within China there is now increasing acceptance even at official levels that all rights, social and economic and civil and political, are indivisible and interdependent. The 2012 Human Rights Action Plan asserts: '[T]aking all types of human rights as interdependent and inseparable, the Chinese government determines to promote the coordinated development of economic, social and cultural rights as well as civil and political rights, and the balanced development of individual and collective human rights' (State Council Information Office 2012). It becomes clear in the discussion in this book's case studies that the capacity of individuals to enjoy social and economic rights is strongly impacted by enjoyment (or lack of enjoyment) of their rights to personal security, to assemble, associate and to express their views in public and through the media.

The Party-state adopts a positivist view of rights which views rights as granted by the Party-state. That is, as a consequence of legislation. Law is the primary vehicle through which rights are given form and their specific meaning. The Constitution sets out the rights enjoyed by citizens and their corresponding duties. For these rights to be given specific form, legislation is required which defines both the nature and extent of the right and prescribes the means for its implementation and enforcement. These laws must in the ordinary course be read in the context of core policies such as the Harmonious Society policy which influence the ways in which legal prescriptions are interpreted and implemented. This view of human rights stands in sharp contrast with the international and natural law approach to rights that views rights as being inherent in individuals by virtue of being human. In such a view human rights are universal and inalienable (Kent 1993, 7).

As is common in socialist states, there is a largely positive view of rights in that state action is required for their realisation. As a consequence, regulation of citizens' legal rights places the preponderance of power and responsibility on agencies of state for implementation, supervision and enforcement of the law. Active state participation is also mandated by the nature of social and economic rights themselves such as provision of social security, ability to access housing and medical care and the right to work, be paid and enjoy reasonable work conditions as they commonly involve claims on the state. The Human Rights Action Plan reiterates this state-led and positive approach to the definition and protection of rights and interests. The $12^{\text {th }}$. Five-year Plan as well explicitly provides for improvement of the mechanisms for protection of the people's lawful rights and interests through strengthening the Party-state's leadership, 'implementing a scientific and effective mechanism for coordinating interests, for making claims and resolving conflicts'. This positive approach has traditionally been contrasted with the negative views of rights which prevent the state from interfering in certain types of freedoms (Woo 1993, 181-2). However, the distinction 
should not be drawn too sharply between civil and political and social and economic rights as both sets of rights have positive and negative aspects to them. One example discussed in relation to labour rights in chapter 2 is the anti-discrimination provision of the Employment Promotion Law which has enabled groups to use focused anti-discrimination litigation to seek to improve the overall workplace conditions of disadvantaged groups.

The state-led nature of social and economic rights suggests to some commentators that the availability and strength of private enforcement mechanisms is less important or apposite than it might be to enforce other rights such as negative rights to prevent the state from interfering in civil or political rights. Some aspects of social and economic rights, such as whether the state has taken necessary steps to achieve progressive realisation of these rights, involve policy and resourcing decisions that are not amenable to individual dispute resolution in a court (Peerenboom 2010-2011, 311-316). The inquiry in this book is somewhat different as it examines the capacity of individuals and groups to make claims and enforce rights that have been given specific definition by law and for which the law also specifies modes of enforcement. It thus considers the capacity of individuals to access the law and the mechanisms provided in the law rather than a broader question of whether social and economic rights may be advanced or protected by litigation. Whilst individuals are empowered to pursue breaches of their rights through the courts and administrative review mechanisms, these channels of complaint are, in different ways, limited. A theme explored in this book is the extent to which and ways in which individuals are able to press claims through formal channels, as well as the nature and types of restrictions and limitations on civil society groups, unregistered lawyers and even lawyers in assisting and representing claimants.

Some may wonder whether the legal and policy issues raised by increasing inequality and growing public anger are best framed as a question of rights rather than of justice more broadly. It has already been noted that many disputes and protests are not framed in terms of rights protection but as a demand for compliance with rules. This insight may be used as an argument that the significance of public protests and demands cannot be interpreted as being indicative of the emergence of a new type of political citizenship that might eventually challenge the existing political order (Perry 2008). It is an argument that protests are not politically destabilising, and in their appeal to state agencies to redress wrongs they actually affirm the existing political order. But arguably the question of rights is not exhausted by a question of whether or not protests are framed as rights demands, whether and whether protests challenge the rule of the CCP. An interpretation of the political significance of claims made by citizens either framed as demands based on rules or on rights is a question for another time and not the focus of this book. This book focuses on the legal implications of rights questions; their definition, implementation and the many consequences that flow from failures to give effect to those rights.

The Party-state's commitment to improving the basic livelihood of Chinese people and its own characterisation of this task as a fundamental right squarely raises for consideration its approach to establishing and protecting social and economic rights, which may also be viewed as a core component of distributive justice. In this context a discussion of rights, particularly rights fundamental to livelihood and human dignity, may be seen as a component, or a building block, of an interrogation of fairness and justice in China's system of governance. The Party-state has thrown its political capital and organisational capabilities behind the establishment of a system of law based governance, under the rubric of rule of law (yifa zhi guo 依法治国). Failures to implement the laws 
that define rights in the domestic environment undermine the capacity of citizens to enjoy or to demand respect for these rights. So, systematic failures of law-based governance to fulfil promises made in law about rights are damaging to the authority of the law and ultimately to the Party.

An examination of the ways in which rights are enacted in law and given effect through law arguably provides one way of addressing the broader issue of distributive justice. This practical approach to an examination of the definition and realisation of rights is grounded in a view of justice that focuses on the practical steps that might be taken toward improving social justice and how better protection of rights might contribute to realisation of that ideal. As Sen (2009) puts it, it is necessary to consider what steps may be taken to remove injustice. In this book I focus on the ways in which institutional arrangements of state power and state policies both define and give effect to those rights. They set the limits on the extent to which and the ways in which rights can be enjoyed. Whilst a great deal can be learned about China's progress in protecting rights through rankings in international indices, such as the United Nation's Human Development Index, these aggregate numbers and rankings also leave out a lot. The proportion of GDP spent on primary health care, for example, cannot capture the different experiences of primary health care provision of the richest and poorest in the country. As the differentiation between levels of wealth and provision of services between the richest and poorest of China's citizens grows, so does the need to attempt to capture differently located voices. Patricia Williams reminds us that the experience of rights and their significance differs between differently located individuals (Williams 1991). This book seeks to capture a range of different voices through examining laws and policies that define and give effect to rights. It also considers the ways in which claims for protection of those rights, or more accurately claims to uphold the law that defines those rights, are framed and responses to those claims.

$<2>$ The Structure of this Book

The material in this book is organised as a series of case studies. The book does not seek to provide a comprehensive account of human rights as they are implemented in China, or to develop an overall theory about the relationship between rights and stability in China's system of governance. Its purpose is to explore the multiple, shifting ways in which stability imperatives impact on the legal definition and implementation of rights, and the outcomes of these interactions for the evolving project of governance according to law. Each of the case studies is on a topic of fundamental importance to the realisation of the Party-state's stated goals of improving people's livelihood and respecting human dignity. The case studies were chosen because of both their centrality to people's livelihoods and because failures to date in these areas have a direct and significantly negative impact on people's livelihoods, are the focus of significant dissatisfaction and are the cause of a high proportion of socially disruptive behaviour in the form of petitioning and mass incidents.

The use of case studies enables a detailed examination of the legal regulations which give concrete form to these rights, an evaluation of enforcement modes and an evaluation of the areas of weakness and failings in enforcing those rights. It also enables an examination of the varying state responses to the protests arising out of these failings. Chapter 1 has described the primary questions under examination and explained some of the central concepts.

Chapter 2 examines the problem of labour unrest. The dilemma for the Party-state lies in the fact that the increase in labour disputes, especially large, public protests not only signals systemic problems with China's industrial relations system and the ability of employees to assert and enforce 
their rights, but also raises fears about the potential for this unrest to lead to broader social and political instability. Of concern is the possibility for accumulated labour-related grievances to trigger large scale riots. This chapter examines the multi-pronged approach adopted to deal with the problem of industrial unrest. One approach has been to adopt both short and long term measures designed to rectify the worst abuses, with 'rights protection' a means of promoting social stability. These measures include extensive legislative reform and attempts to strengthen the will of unions more effectively to represent worker interests. However, these reforms have not, so far at least, changed the underlying regulatory structure of the labour market which has individualised labour relations and downplayed collective empowerment. In parallel there has been a focus on the management of stability, through a web of early warning and early intervention strategies to prevent escalation of disputes. Perceptions that the Party-state is confronting a social order crisis has undergirded development of a range of Party-led coordinated administrative measures, including enforcement campaigns, which involve mobilisation of Party, state and other agencies. Finally, protests that have become large and violent are re-characterised as a riot, and so an antagonistic contradiction, and suppressed with violence. Where leaders can be identified they are punished severely.

Chapter 3 examines forced housing demolition and relocation. Urban renewal projects undertaken by local governments have led to many urban residents being forcibly removed and having their homes demolished in ways they consider grossly unjust. In these developments the interests of local governments are aligned with developers against those of residents. This conduct has been a major source of popular dissatisfaction and caused widespread public protest. A number of factors underlie these problems including; the loose definition of legal rights; the effective merger of public and private interests in the manner rights to land are allocated and demolition rights granted and carried out; and the lack of effective legal redress for unconscionable or unlawful conduct. This chapter examines the recent reforms to regulations on forced housing evictions that were intended to rectify some of the worst abuses by developers and local governments, but which at the same time strengthen punitive powers in relation to people who refuse to cooperate. It examines people's grievances in their own voice through four petition letters that set out each individual grievance, their struggle for justice and their appeal for redress for unlawful expropriation and inadequate compensation. We see though, that protesters and those willing to support them are often met with force by agents of the developer and local government. In this chapter we see the limits of reforms that address procedural issues to do with housing demolition and eviction but fail to address the underlying cause of the problem. That problem is driven by reliance on land and property sales by local governments to finance their budgets and the collusive relationships formed in and around real estate development. The contrary example of minor property housing, where the interests of peasants, local governments and developers are aligned illustrates the fundamentally financial sources of the problem of land and housing expropriation.

Chapter 4 examines medical disputes. Privatisation of China's health care system laid the groundwork for the steadily increasing public anger about availability and quality of medical care. Recent reforms to increase public financing of primary health care has done little to reduce the levels of direct and sometimes violent actions being taken by aggrieved patients and their families against doctors and health workers in hospitals. This chapter examines the factors that have tended to divert grievance resolution procedures away from formal medical arbitration and civil dispute resolution processes to forms of direct action and protest against health professionals and hospitals. 
It traces the range of state responses to these forms of social disturbance; tentative but ultimately minimal legislative reform of formal dispute resolution processes, introduction of specialist medical disputes mediation committees, efforts to reshape popular attitudes about the doctor patient relationship in the form of television programming, and expansion of the range of conduct punishable on the grounds of disrupting social order in both administrative and criminal law. Finally, a series of violent attacks and murders in hospitals near the end of 2013 triggered a nationwide campaign. This one year campaign is designed to coordinate responses to medical dispute related disruption and violence and to strengthen the severity of punishments to be imposed on those engaging in violent conduct against doctors, hospital staff and hospitals. In a different context from labour and housing disputes we see replicated a range of responses to public dissatisfaction: steps to rectify underlying problems; introduction of coordinated measures to address disruptive conduct and disputes; and strengthening of punitive responses against those who persist with disruptive or violent conduct.

Chapter 5 examines in more detail the array of coercive measures, broadly defined, taken to target protest and socially disruptive conduct. These include programs to discover dissatisfaction that may develop into protest, and to manage, resolve, or to defuse protests early before they develop. A range of educational strategies are also used to influence public opinion. The backdrop for these strategies is the array of coercive and punitive powers exercised by justice agencies to punish conduct identified as troublemaking, disruptive of social order or which constitutes plain criminal offending. This chapter discusses the example of petitioning conduct to illustrate changing state tolerance of disruptive conduct. It illustrates the ways in which legal interpretations and rules define an increasingly narrow range of acceptable petitioning conduct. In doing so, they increase the reach of administrative and criminal punitive powers, both lawful and unlawful, to sanction conduct that falls outside the bounds of acceptable petitioning.

Chapter 6 examines the impact and significance of abolition one of China's most infamous administrative punishments, re-education through labour (RETL). It examines the impact of its abolition in terms of the totality of state powers to punish socially disruptive conduct. It also considers the significance of its abolition in terms of rights protection. An examination of the debates about reform or abolition of RETL prior to its final demise reveal a growing awareness of basic human rights norms as well as a growing willingness to embrace those norms. However evaluations of what legal and institutional changes needed to be instituted to comply with those norms differed widely. In particular there was considerable disagreement about for how long a person could be detained under an administrative sanction and what forms of decision-making and oversight were required to avoid arbitrariness. Questions about how to balance the value of protection of rights with the value of protecting social stability was commonly assumed to be a balancing act, where protecting individual rights would be at the expense of social stability. Only a few voices suggested that protection of rights, through promoting social fairness and justice might help to improve social stability. The emerging consensus before abolition of RETL that it was not an efficient way of protecting social stability means that the question of the relationship between rights and stability in the context of punitive powers remains open.

Finally, chapter 7 brings these case studies together. Each of these chapters reveals a range of ways in which stability concerns impact on the enjoyment of rights. Rights protection may be used as a means of stability protection and is seen in legal and policy steps to remediate problems. Stability 
protection is often used as a reason for increasingly punitive approaches to dealing with protests and petitions. Social stability considerations impact on forms and outcomes of dispute resolution and are implicated in the increasing use of mediation to resolve rights related disputes. Stability concerns have prompted the use of comprehensive management tools to intervene in the regulatory sphere to restore stability. Finally we are left with questions about the circumstances in which rights protection is seen as contributing to stability protection and when stability protection becomes a value to be pursued even at the expense of rights protection. The range of interactions between stability concerns and law making and enforcement as it affects a range of rights illustrates the many ways in which demands for social and political stability shape the development of the rule of law and governance in China.

\footnotetext{
i Throughout I use the term Party-state as it best captures the nature of governance in China. That is; of an authoritarian state with a single ruling party, the Chinese Communist Party (CCP), where the CCP exercises its leadership role directly and through its control of the organs of state. (Zhu 2007) 535 asserts that as the 'CCP's influence and control is ubiquitous' and that it in fact inherited the political tradition of the KMT of the Partystate of 'party construction of the state' and where the 'party [is] above the state'.

ii Taizhou is a prefecture level city on the coast in Zhejiang province. At the 2010 census it had a population of nearly 6 million people.

iii 18 October 2006, reproduced at http://cpc.people.com.cn/GB/64093/64094/4932424.html

iv http://www.qjzfw.gov.cn/gonggao/20121224/160541.shtml
} 


\section{University Library}

\section{- M M N E R VA A gateway to Melbourne's research publications}

Minerva Access is the Institutional Repository of The University of Melbourne

Author/s:

Biddulph, S

Title:

The Stability Imperative Human Rights and Law in China

Date:

2015

Citation:

Biddulph, S. (2015). The Stability Imperative Human Rights and Law in China. (1), UBC Press.

Persistent Link:

http://hdl.handle.net/11343/252733 